\title{
Selection of suitable housekeeping genes for gene expression analysis in glioma using quantitative real-time PCR
}

\author{
Madhuri GS Aithal, Narayanappa Rajeswari \\ From International Conference on Human Genetics and 39th Annual Meeting of the Indian Society of \\ Human Genetics (ISHG) \\ Ahmadabad, India. 23-25 January 2013
}

\section{Background}

Quantitative real-time PCR (qPCR) is the most reliable tool for gene expression measurements from tissue samples. Selection of housekeeping genes (HKGs) that are most stably expressed among tissues is vital to carry out accurate gene expression profiling of target genes. Expression of HKGs varies among tissues and experimental conditions. There is no 'universal' housekeeping gene having stable expression in all tissues under all experimental conditions. So, it is extremely important to identify most appropriate internal control genes for a particular tissue and experimental conditions. The aim of the present study is to identify most suitable HKGs for gene expression analysis in glioma tissue samples.

\section{Material and methods}

Based on literature survey six most commonly used HKGs reported to be invariant in human gliomas were chosen for gene expression analysis. We performed qPCR using RNA from formalin fixed paraffin embedded glioma patient samples and normal brain samples to investigate the expression pattern of six HKGs [Glyceraldehyde-3phosphate dehydrogenase (GAPDH), hypoxanthine phosphoribosyltransferase 1 (HPRT), $\beta 2$ microglobulin (B2M), TATA-binding protein (TBP), $18 \mathrm{~S}$ ribosomal RNA (RN18S1) and ribosomal protein L13a (RPL13A)] with different abundance. A simple $\Delta \mathrm{Ct}$ approach was employed to calculate the fold change.

* Correspondence: nraja7@gmail.com

Department of Biotechnology, Dayananda Sagar College of Engineering, Bangalore, Karnataka, India- 560078
Submit your next manuscript to BioMed Central and take full advantage of:

- Convenient online submission

- Thorough peer review

- No space constraints or color figure charges

- Immediate publication on acceptance

- Inclusion in PubMed, CAS, Scopus and Google Scholar

- Research which is freely available for redistribution 